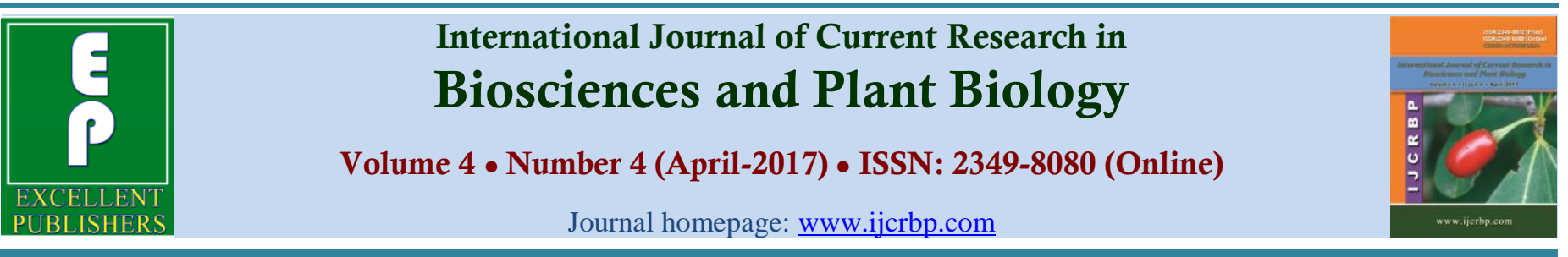

\title{
Effect of Liquid Organic Fertilizer MIKROBAT on Vegetative Growth of Local Aromatic Rice in Enrekang, South Sulawesi
}

\author{
A. Masniawati*, Sri Suhadiyah, Elis Tambaru and Dewi Sulastri Anwar
}

Department of Biology, Faculty of Mathematics and Natural Sciences, University of Hasanuddin, Tamalanrea 90245, Makassar, Indonesia

*Corresponding author.

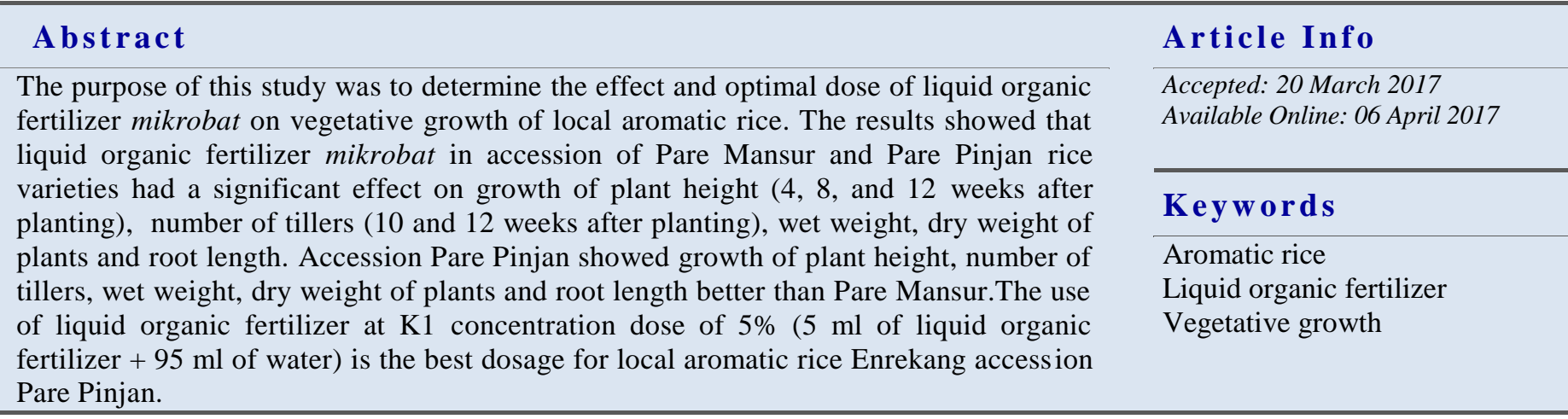

\section{Introduction}

Rice (Oryza sativa L.) is the most important food crops are planted nearly a third of total amount of food in the world (Purwono and Purnamawati, 2007). Enrekang local aromatic rice is one type of aromatic rice that has a pungent scent (Rice Research Institute, 2002). One effort to increase productivity of rice plants is to meet nutrient needs.Fertilization aims to add nutrients needed by plants because nutrients contained in soil is not always sufficient to stimulate optimal plant growth (Salikin, 2003).

Organic fertilizer is the result of decomposition of organic materials are decomposed by microbes, the end of result could provide some nutrients that plants need for growth and development of plants (Supartha et al., 2012). Liquid organic fertilizer is a compound fertilizer even called a complete fertilizer due to the nutrient contents (both macro and micro) with different concentrations (Lingga and Marsono, 2004).

\section{Materials and methods}

Erect Two local aromatic rice accessions Enrekang namely accession Pare Pinjan (PP), and Pare Mansur (PM). Seeds are selected and then soaked with water. Immersion aims to soften the husks of grain so as to accelerate seed to germinate.Soaking for 24 to 48 hours. Once the seeds are soaked and appeared a little sprouts/ roots then planted into the bucket.Each bucket filled with 3 seeds. Application of liquid organic fertilizer 
mikrobat carried out in accordance with a predetermined concentration.concentration used is K1 (I concentrations at a dose of 5\%), K2 (II concentration at a dose of 10\%) and K3 (III concentrations at a dose 15\%). Fertilization is done three times, namely when the plants aged 2, 4 and 6 weeks after planting. Treatment plants include watering and weeding.

\section{Results and discussion}

Quantitative data were analyzed using F test. If there is a treatment that significantly will be a further test using DMRT (Duncan Multiple Range Test) (Soplanit and Nukuhaly, 2012). Analysis results of variance showed that mikrobat liquid fertilizer and urea fertilizer (N, P, K recommendation) on the plant aromatic rice has not shown a good effect on some growth parameters were observed.Parameter observations include vegetative growth, such as plant height, number of tillers, wet weight, dry weight of plants and root length.

\section{Plant height of local aromatic rice Oryza sativa L.}

Plant height growth forstatistical analysis of interaction between treatment of liquid organic fertilizer mikrobat with accession Pare Mansur and Pare Pinjan age of 12 Weeks After Planting (WAP) showed significantly different results. According to Dwi (2006) in Kasniar and Supadma (2007) each plant with a given dose will affect the size of nutrient content in the fertilizer, but can not be guaranteed that the greater the dose given will increase plant growth. Because plants also have certain limits that cause results increased, and at concentrations that exceed a certain limit will also lead to declining results and also plant will grow well if nutrients are given in numbers proportionate and commensurate with the needs of plant (Mappangarno et al., 2011).

Table 1. Analysis results of interaction between liquid organic fertilizer Mikrobat treatment with accession Pare Mansur (PM) and Pare Pinjan (PP) against height of plants 12 weeks after planting.

\begin{tabular}{lll}
\hline Treatment & Average value $(\mathbf{c m})$ & Comparative value (Duncan 5\%) \\
\hline K0 $0^{+}$PM & $76.59^{\mathrm{a}}$ & 12.74 \\
K3 PP & $93.54^{\mathrm{b}}$ & 13.38 \\
K0 PM & $94.61^{\mathrm{b}}$ & 13.77 \\
K1 PM & $95.34^{\mathrm{b}}$ & 14.03 \\
K2 PP & $95.36^{\mathrm{b}}$ & 14.24 \\
K2 PM & $96.53^{\mathrm{b}}$ & 14.37 \\
K1 PP & $97.68^{\mathrm{b}}$ & 14.46 \\
K3 PM & $100.27^{\mathrm{b}}$ & 14.54 \\
K0 PP & $101.33^{\mathrm{b}}$ & 14.63 \\
K0- PP & $104.87^{\mathrm{b}}$ & - \\
\hline
\end{tabular}

Number followed by the same letter in the same row or column are not significantly different by Duncan's Multiple Range Test DMRT at 5\% level.

From the average data (Table 2) it can be seen that accession Pare Pinjan have better growth compared to Pare Mansur. Differences in the growth of both accessions to vegetative observation, thought to be caused by differences in nature or superiority of each accession in accordance with its genotype. According Setyamidjaja (1986) suggest that growth is progressive development of an organism and is strongly influenced by genetic and environmental factors where main environmental factors that influence fertilization treatment is given. According Taslim and Fagi (1988) that the plant height is strongly influenced by genetic factors and growth environment, genetic trait would appear through organ growth if appropriate environmental factors.
Table 2. Results of analysis on both accessions Pare Mansur (PM) and Pare Pinjan (PP) against height of plants 4 and 12 weeks after planting.

\begin{tabular}{lll}
\hline Accession & $\begin{array}{l}\text { Average value (cm) } \\
\text { [4 WAP] }\end{array}$ & $\begin{array}{l}\text { Average value (cm) } \\
\text { [12 WAP] }\end{array}$ \\
\hline Pare Mansur & $82.24^{\mathrm{a}}$ & $277.99^{\mathrm{a}}$ \\
Pare Pinjan & $97.42^{\mathrm{b}}$ & $295.66^{\mathrm{b}}$ \\
\hline
\end{tabular}

Number followed by the same letter in the same row or column are not significantly different by Duncan's Multiple Range Test DMRT at 5\% level.

Many factors lead to the treatment of liquid organic fertilizer mikrobat vary on growth and yield of rice plants. Plant height increased with the amount of $\mathrm{N}$ uptake by plants. Nitrogen fertilization can support the growth of rice plant because nitrogen serves stimulate vegetative 
growth of plants. Besides the content of microorganisms contained in a liquid organic fertilizer mikrobat function as an anti-toxin, so it can nourish the plants, supplying of nutrients and hormones to plant, decomposing organic matter and protect plants from pathogen attack so that it can accelerate plant growth.Prajnanta (2004), that the organic fertilizer in liquid form is more effective because it can go directly intosoil, can also easily reach places through which the roots.

\section{Number of tillers in local aromatic rice Oryza sativa $\mathbf{L}$.}

Results of statistical analysis known that the interaction between the treatment of liquid organic fertilizer mikrobat with Pare Mansur and Pare Pinjan accession aged 10 and 12 WAP showed significantly different results.Number of tillers is one of the growth parameters used to determine the influence of environment and treatment conducted in field, in addition to number of tillers is also used as a basis in determining productivity of crops. The number of tillers were produced after administration of liquid organic fertilizer on local rice Enrekang shown the ability to adapt to its environment. Organic fertilizers provide beneficial effects in addition to safe for environment also have a positive effect on plant because it contains growth hormones and beneficial microorganisms plants.

Table 3. Analysis results of interaction between liquid organic fertilizer Mikrobat treatment with accession Pare Mansur (PM) and Pare Pinjan (PP) against number of tillers 10 and 12 weeks after planting.

\begin{tabular}{lll}
\hline Treatment & $\begin{array}{l}\text { Average value (cm) } \\
{[\mathbf{1 0} \text { WAP] }}\end{array}$ & $\begin{array}{l}\text { Average value (cm) } \\
{[\mathbf{1 2} \text { WAP] }}\end{array}$ \\
\hline K0 PM & $3.33^{\mathrm{abc}}$ & $3.33^{\mathrm{ab}}$ \\
$\mathrm{K} 0^{-} \mathrm{PP}$ & $5.44^{\mathrm{c}}$ & $8.00^{\mathrm{cd}}$ \\
$\mathrm{K} 0^{+} \mathrm{PM}$ & $1.33^{\mathrm{a}}$ & $1.78^{\mathrm{a}}$ \\
$\mathrm{K} 0^{+} \mathrm{PP}$ & $3.89^{\mathrm{bc}}$ & $9.56^{\mathrm{d}}$ \\
$\mathrm{K} 1 \mathrm{PM}$ & $5.44^{\mathrm{c}}$ & $3.56^{\mathrm{ab}}$ \\
$\mathrm{K} 1 \mathrm{PP}$ & $4.78^{\mathrm{bc}}$ & $5.89^{\mathrm{bc}}$ \\
$\mathrm{K} 2 \mathrm{PM}$ & $4.22^{\mathrm{bc}}$ & $3.89^{\mathrm{ab}}$ \\
$\mathrm{K} 2 \mathrm{PP}$ & $2.56^{\mathrm{ab}}$ & $3.11^{\mathrm{ab}}$ \\
K3PM & $6.00^{\mathrm{d}}$ & $4.56^{\mathrm{ab}}$ \\
K3PP & $3.89^{\mathrm{bc}}$ & $4.89^{\mathrm{bc}}$ \\
\hline Number followed by the same letter in the same row or \\
column are not significantly different by Duncan's Multiple \\
Range Test DMRT at 5\% level.
\end{tabular}

\section{Wet weight, dry weight and root length of local aromatic rice Oryza sativa $\mathrm{L}$.}

Results of statistical analysis known that the interaction between the treatment of liquid organic fertilizer mikrobat with Pare Mansur and Pare Pinjan accession for wet weight and dry weight of plants showed significantly different results.

Table 4. Analysis results of interaction between liquid organic fertilizer Mikrobat treatment with accession Pare Mansur (PM) and Pare Pinjan (PP) against wet weight and dry weight of local aromatic rice.

\begin{tabular}{|c|c|c|}
\hline Treatment & Wet weight (g) & Dry weight (g) \\
\hline K0ㅜ PM & $21.34^{\mathrm{a}}$ & $10.66^{\mathrm{ab}}$ \\
\hline $\mathrm{K} 0^{-} \mathrm{PP}$ & $82.44^{\mathrm{bc}}$ & $22.30^{\mathrm{cd}}$ \\
\hline $\mathrm{K}^{+}{ }^{+} \mathrm{PM}$ & $15.19^{\mathrm{a}}$ & $7.28^{\mathrm{a}}$ \\
\hline $\mathrm{K}^{+} \mathrm{PP}$ & $105.79^{c}$ & $24.20^{\mathrm{d}}$ \\
\hline K1 PM & $40.63^{\mathrm{ab}}$ & $11.04^{\mathrm{ab}}$ \\
\hline K1 PP & $58.27^{\mathrm{abc}}$ & $16.89^{\mathrm{abcd}}$ \\
\hline K2 PM & $27.71^{\mathrm{a}}$ & $17.49^{\mathrm{bcd}}$ \\
\hline K2 PP & $28.31^{\mathrm{a}}$ & $8.61^{\mathrm{ab}}$ \\
\hline К3РM & $23.79^{\mathrm{a}}$ & $14.26^{\mathrm{abcd}}$ \\
\hline K3PP & $58.55^{\mathrm{abc}}$ & $12.01^{\mathrm{abc}}$ \\
\hline
\end{tabular}

Number followed by the same letter in the same row or column are not significantly different by Duncan's Multiple Range Test DMRT at 5\% level.

In comparison given containing urea fertilizer $\mathrm{N}$ sources, KCL source $\mathrm{K}$ and SP-36 as a source of $\mathrm{P}$ is an appropriate gift because they contain macro nutrients that plants need. According Syekhfani (1994), nitrogen fertilization can support the growth of rice crops due to nitrogen serves stimulate vegetative growth of plants. Increased yield crop weights can achieve optimal results, because plants obtain nutrients required so that an increase in number and size of the cell can achieve optimum and allows an increase in water content optimal plant anyway. According to Loveless (1987) most of wet weight of plants caused by water content.

Furthermore, according to Gardner et al. (1985) generally plant wet weight fluctuates widely, depending on circumstances of moisture plants, while according Jumin (2002) states that amount of water required each phase of growth depends on the physiology, morphology and environmental factors.

Table 5. Result of analysis on both accessions Pare Mansur (PM) and Pare Pinjan (PP) against wet weight and dry weight of plants.

\begin{tabular}{|c|c|c|}
\hline Treatment & Wet weight & Dry weight \\
\hline Pare Mansur & $77.2^{\mathrm{a}}$ & $36.43^{\mathrm{a}}$ \\
\hline Pare Pinjan & $200.02^{b}$ & $50.4^{\mathrm{b}}$ \\
\hline \multicolumn{3}{|c|}{$\begin{array}{l}\text { Number followed by the same letter in the same row or } \\
\text { column are not significantly different by Duncan's } \\
\text { Multiple Range Test DMRT at } 5 \% \text { level. }\end{array}$} \\
\hline
\end{tabular}


Differences in respective accession occurs because of genetic differences in two accession and their environmental effects.Each accession has characteristics and special properties that influence each other so it will show diversity of appearance. As stated by Loveless (1989) a phenotype of an individual is result of interaction between genotype and environment.Although the characteristics of a particular phenotype can not always be determined by difference in genotype or environment, there is possibility of phenotypic differences between individuals who are separated due to environmental differences or differences between them.

Table 6. Result analysis of effect organic liquid fertilizer Mikrobat treatment against root length of local aromatic rice.

\begin{tabular}{ll}
\hline Treatment & Average value \\
\hline $\mathrm{K} 0^{-}$ & $116.63^{\mathrm{b}}$ \\
$\mathrm{K} 0^{+}$ & $92.40^{\mathrm{a}}$ \\
$\mathrm{K} 1$ & $136.87^{\mathrm{c}}$ \\
$\mathrm{K} 2$ & $111.90^{\mathrm{b}}$ \\
$\mathrm{K} 3$ & $119.90^{\mathrm{b}}$ \\
\hline
\end{tabular}

Number followed by the same letter in the same row or column are not significantly different by Duncan's Multiple Range Test DMRT at 5\% level.

Root growth response was quite good after administration of liquid fertilizer due to the nutrients contained in liquid organic fertilizer. The success of plant growth is determined by development of roots. The roots of plants should be in an environment that is capable of providing structural support, allowing absorption of water and availability of adequate nutrition. In addition, growing media allows good drainage and $\mathrm{pH}$ for plants (Ingels, 1985). Growth of rice plant biomass is determined by adequacy of $\mathrm{N}$ and $\mathrm{P}$, while for root growth is largely determined by adequacy of P (Dobermann and Fairhust, 2000). Phosphorus is one of micro-nutrients essential for plant growth. Although plants require $\mathrm{P}$ less than $\mathrm{N}$, but $\mathrm{P}$ is needed to produce energy and the speed of plant growth (Chien et al., 1990).

\section{Conclusion}

Mikrobat liquid organic fertilizer on the accession of Mansur and Pare Pare Pinjan show significant effect on growth of plant height (4, 8 and 12 Weeks After Planting, number of tillers (10 and 12 Weeks After Planting), wet weight of plants,dry weight and root length of plant.Accession Pare Pinjan shows vegetative growth better than Pare Mansur. The best concentration of liquid organic fertilizer mikrobat on accession Pare Pinjan namely concentration (K1) 5\% and the best dosage for accession Pare Mansur generally at concentrations (K3) $15 \%$.

\section{Conflict of interest statement}

Authors declare that they have no conflict of interest.

\section{References}

Chien, S.H., Sale, P.W.G., Hammond, L.L., 1990. Comparison of the Effectivennes of Phosphorus Fertilizer Product. Procedings of Symposium 6-10 March 1989. International Rice Reseach Institute, Los Bonos, Philippina.

Dobermann, A., Fairhust, T., 2000. Rice Nutrient Disorders and Nutrient Management. Oxford Graphics Printers Pte. Ltd. 191p.

Dwi, C. O., Rejeki. A., Teguh, S., 2006. Dose effect of liquid organic fertilizer and type of soil on the growth of Dewa Crown (Phalleria macrocorpa). Tunas Pembangunan University, Surakarta. 10p.

Gardner, F.P., Pearce, B.R., Roger, L.M., 1985. Physiology of Crop Plants. The Iowa State University Press, Iowa.

Ingels, J.E., 1985. Ornamental Horticulture. Principles and Practices State University of New York Agricultural and Technical College. Delmar Publisher Inc. 542p.

Jumin, H.B., 2002. Agroecology: An Approach Physiology. PT. King Grafindo Persada, Jakarta.

Kasnari, D.N., Supadma, N., 2007. Effect of multiple doses fertilizer $(\mathrm{N}, \mathrm{P}, \mathrm{K})$ and type of alternative fertilizer on the result of rice (Oryza sativa L.), and levels of N, P, K Inceptisol, Selemadeg Tabanan, Bali. Faculty of Agriculture, Udayana University.

Lingga, P., Marsono, 2004. Instructions for Use Fertilizer. Editors Agromedia, Jakarta.

Loveless, A.R., 1987. Principles of Plant Biology for Tropical Regions. Publisher PT. Gramedia, Jakarta.

Loveless, A.R., 1989. Principles of Plant Biology for Tropical Regions. Translation K. Kartawinata, and U. S. Dinimiharja Soetisna. Gramedia, Jakarta.

Mappanganro, N., Sengini, E.L., Baharuddin, 2011. Growth and Production Plant Strawberries on Range of Liquid Organic Fertilizer Concentration and Cow Urine with Hydroponics System Drip Irrigation. Faculty of Agriculture, University of Hasanuddin. Makassar, South Sulawesi.

Prajnanta, F., 2004. Agribusiness chili Hybrids. Penebar 
Swadaya, Jakarta.

Purwono, Purnamawati, H., 2007. Cultivation of 8 Superior Food Crops. Penebar Swadaya, Jakarta.

Rice Research Institute, 2002. Description Rice Varieties. Research Firm and Agricultural Development.

Salikin, K.A., 2003. Sustainable Agriculture Systems. Publisher Doubleday, Yogyakarta.

Setyamidjaja, D., 1986. Fertilizer and Fertilization. Simplex, Jakarta. 122p.

Soplanit, R., Nukuhaly, S.H., 2012. Effect of NPK nutrient management against the availability and results rice Oryza sativa L. in the village Waelo, Waeapo, Buru District. Agrologia J. 1(1), 81-90.

Supartha, I.N., Wijana, G., Adnyana, M.G., 2012. Application type of organic fertilizer on organic rice farming systems. E-J. Trop. Agroecotech. 1(2), 98106.

Syekhfani, 1994. Groundwater Plant. Brawijaya University Press, Malang.

Taslim, H., Fagi, A.M., 1988. Cultural Variety of Rice in Rice Book 1. Agency for Agricultural Research and Development. Center for Food Crops Research and Development. Bogor.

\section{How to cite this article:}

Masniawati, A., Suhadiyah, S., Tambaru, E., Anwar, D. S., 2017. Effect of liquid organic fertilizer MIKROBAT on vegetative growth of local aromatic rice in Enrekang, South Sulawesi. Int. J. Curr. Res. Biosci. Plant Biol. 4(4), 2024. doi: https://doi.org/10.20546/ijcrbp.2017.404.004 